A multi-perspective exploration of the development of academic identity in a School of Education

Elizabeth White*, Amanda Roberts, Mary Rees and Mary Read

University of Hertfordshire, UK

*corresponding author

Dr E.White

School of Education

University of Hertfordshire

de Havilland Campus

Hatfield

Hertfordshire

AL10 9AB

Tel: 01707285766

Email: e.j.white@herts.ac.uk 


\title{
A multi-perspective exploration of the development of academic identity in a School of Education
}

\begin{abstract}
This paper explores the complex processes involved in the self-construction of academic identity in a UK School of Education. Drawing on the research of four academics, it begins by discussing teacher educators' varying perceptions of the need to re-configure their identity to meet the expectations of a twenty first century Higher Education workforce. It proposes the formation of this identity to be a dynamic, career-long process. Diverse scaffolds for the development process are proposed, including opportunities for new teacher educators to be apprenticed into an academic role, the centrality of communities of practice and the importance of the supported development of academic skills such as writing for publication.
\end{abstract}

Keywords: teacher educators; academic identity; multiple identities; communities of practice; apprenticeship; academic writing

\section{Introduction}

In this paper, we suggest that current, on-going changes in the nature and expectations of the university are causing the individuals who work in the Higher Education sector to reconsider their identity. This individual response is particularly important in times of institutional uncertainty. Drawing on multiple viewpoints, including those of a new teacher educator, we begin by exploring what is understood by identity, both on an institutional and individual level. We surface the debate about the dynamic nature of this identity - how it is configured, held and re-configured. We move on to investigate various individual perspectives of how the development of identity in a University School of Education setting can be supported. We propose a number of scaffolds for the development process, including opportunities for new teacher educators to be apprenticed into an academic role, the surfacing of communities of practice and targeted support programmes for the development of academic skills such as writing for publication. The concepts of substantive and situational identity are used to illuminate our developing understanding of identity formation. We conclude by considering the implications of our research for the development of teacher-educators' expertise and confidence in a rapidly changing environment.

\section{The Higher Education Landscape}

The landscape of Higher Education (HE) in the UK is changing as a result of national and international influences. Increased competition as the sector expands, pressure on public funding, digitalisation, globalisation and the shift toward a knowledge economy are resulting in individual universities both evolving and making overt choices as to where to position themselves in this new landscape. The relationship between universities and the state, the purpose of higher education and its function in society and the nature of the knowledge essential to the concept of the graduate are long term areas of interest for those concerned with the philosophy and history of higher education. Barnett (1990) for 
example describes 'the epistemological and sociological undermining of higher education' and is concerned with

... massive changes in higher education worldwide - the neo-liberal turn and the marketization of higher education and the repositioning of higher education for the learning economy. (Barnett, 2007:9)

McCaffery (2004) discusses the university 'identity crisis', suggesting that universities today lack the unifying vision which has been evident in the past. Whitchurch (2007) concurs:

... new discourses are not only challenging assumptions, but are redefining the components of the higher education enterprise in ways that extend and redraw existing categories and classifications. (Whitchurch, 2007: 407)

Deem et al., (2007) suggest a significant twenty first century shift, using the term 'academic knowledge work' to extend the traditional academic activity of teaching and research to include new elements such as consultancy and entrepreneurial endeavour. Whilst acknowledging that this shift was hastened by the incorporation of the post-1992 universities and the move from elite to a mass higher education system, they suggest its basis to be gradual changes to the relationship between state and higher education over the previous two decades. In particular, they point to the introduction of private sector, forprofit mechanisms, with a focus on cost reduction and value for money, into the previously more autonomous Higher Education sector.

Against this backdrop of uncertainty and questioning on political, ideological and economic fronts, universities continue to address the parallel strands of activity traditionally part of a university's concern: providing quality teaching for a broad range of client groups and maintaining academic standing and rigour through research. In addition, the more recent requirement to actively engage with third stream funding (generating funding from non-treasury sources) has moved steadily up the agenda.

\section{Our Research Perspective}

Higher Education Institutions are complex environments of independent agents, tied together by tradition, approximating more to Wenger's (1988, cited White and Weatherby, 2005) notion of a community of practice than a single entity. People are informally bound by what they do together in joint enterprise and thus are not easily represented by a single position or view. The formal relationship between the university as an employer and its academic employees, captured in contracts, national agreements and human resource policies and procedures, is not our concern. Rather, we are interested in the lived experience of individuals working in a university sector that has changed its expectations of academic activity. Whitchurch notes:

... at institutional and sub-institutional levels, individuals are continually redefining what they do, how they might describe this, and how it might be articulated and explained to an ever-widening audience...(Whitchurch, 2007:407)

The commonly accepted understandings of academic identity, discussed below, fail to account for the complexity of this emerging form of university life. 


\section{Institutional and Individual Identities}

The sector's response to change reveals diversity and multiplicity at the level of universities, in turn reflected in the variety of expectations and assumptions made about the engagement of individual academics. The nature of the institution - whether specifically named or implicitly assumed as research intensive, elite, teaching led, corporate or post-92 - appears to be reflected in the experience of those who work within it. For example Archer's (2008) work considering younger academics developing their identity has a strong underlying focus on publication and the particular challenges of moving from 'researcher' status to that of an established academic. This reflects the experience of those in research intensive institutions far more closely than that of academics in a teaching led institution, especially in the professional disciplines. Much empirical and ethnographic work to date has focused on the work of well-established disciplines in elite institutions, with applied disciplines receiving less attention (Macfarlane, 1998).

The model of a research led university where lecturers are in the main recruited from $\mathrm{PhD}$ students who have been socialised into 'a convergent academic community' (Macfarlane, 1998:5) is not necessarily replicated in teaching led institutions, or in applied disciplines such as Education where individuals are recruited externally and come to university lecturing as a second career. The latter may result in research, and more particularly publication, being seen as a 'developmental or aspirational part of their working life rather than key to their identity' (Macfarlane and Hughes, 2009:8) and, even within a research intensive university, the nature and requirements of the research activity can vary substantially. Some universities require individuals to produce world class research whereas others see the establishment of identity as a matter of making a recognisable rather than independent contribution (Henkel, 2005). This dominant representation of elite institutions is further complicated by the myths and discourses which may no longer reflect the reality of academic life, if they ever did, and certainly do not represent the life experienced by those in other strata of Higher Education.

\section{Academic Identities}

A broad discussion of the nature and genesis of identity is beyond the scope of this paper. Here we are concerned with a specific aspect of identity - academic identity - and the influences on its formation and transformation. In particular, we are interested in the development of an academic identity for teacher educators. In considering this issue we are researchers operating within what is almost universally seen as a low status discipline (Macfarlane and Hughes, 2009). Teacher educators frequently feel, and are seen as, 'uneasy residents in academe' (Ducharme 1996, cited Sikes, 2006:558). Rather than providing an impetus to improve disciplinary status, this positioning of education may result in academics adopting an unconcerned attitude to disciplinary boundaries, viewing teaching and research roles as an integrated whole (Macfarlane and Hughes, 2009).

The literature proposes a number of labels for the complex identities of teacher educators, including 'semi-academics' (Ducharme, 1993) and 'second-order practitioners' (Murray, 2004). These complexities in terms of a teacher-educator's identity can be explained to some degree by an examination of the multiple 'expertises' which they are required to maintain, remaining school experts in order to win the trust of student teachers whilst simultaneously becoming full academics. The suggestion that teacher identity is in some way static is therefore problematic. Welmond (2002:42) sees teacher identity to be 'dynamic and contested', shaped by divergent interests and ideologies which themselves 
bring different ways of understanding success or effectiveness. This view is supported by Stronach et al., (2002) who highlight the complex and transitionary nature of professional work. They argue that the contradictions should be embraced rather than attempting to resolve them through typologies of work or activity. Indeed, it could be argued that the complex identity of teacher-educators is currently more representative of contemporary trends in the development of academic identity across HEIs. Embracing a view of academic identity as a dynamic interaction rather than a homogenised isolated construct (Clegg, 2008), we intend to open up definitions and re-consider the disjuncture between 'the rhetoric and experiences of academic life' (Churchman, 2006:8).

\section{Forming and Reforming Academic Identities: an exploration of potential scaffolds}

As stated above, the process of identity development is problematised in much of the literature (Clemans et al., 2010). The concept of professional socialisation, where a new member learns what it is to be part of a new profession (Barnett, 2007) and organisational socialisation, where a person comes to understand the knowledge, values and behaviours needed to perform a particular role within an organisation (Schein, 1985) are useful in exploring the development of teacher educator identity. Blackmore (1999) points to the constant state of change of individual roles within an organisation, based on shifts in the organisation's aims and values. Murray and Male (2005) see time in post as the influencing factor in the move from locating oneself in the old role of teacher to the new role as teacher educator. In our experience, this does not appear to be universally the case at our university in terms of the research aspect of a teacher educators' role. Instead, the support and challenge which individuals receive from others within the organisation and the perceived culture of that organisation seem to be more influential for many.

In this paper, we conceptualise this support in the form of three scaffolding devices: the apprenticeship of teacher educators, the accessing of communities of practice and the development of an academic writing support programme. Our discussion of apprenticeship draws on the work of Lave and Wenger (1991), investigating how their constructs of adept and apprentice can be used to understand the developing identity of an academic in a School of Education. The concept of communities of practice is similarly drawn from Lave and Wenger's (1991) work. Communities of practice provide opportunities to learn through social relationships and co-participation in joint enterprise (Lave and Wenger, 1991). New members benefit from a shared collection of resources (including vocabulary and documents) that members have developed over time. In this paper, we explore how this concept can be applied to experienced teachers in schools who, although undertaking the role of teacher educators, are removed from the conventional communities of practice which substantive work in a university provides. Our discussion of academic writing programmes focuses on an investigation of the activity of writing as a process in the development of academic identity.

We use the concept of the substantive and situational self to develop our understanding of identity development still further. The substantial self is based on a core of self-defining beliefs, often formed through general life experiences, whereas the situational self is developed through interaction with others and can be re-framed when circumstances alter (Nias, 1989). If these are out of alignment, then the basis of the substantial self appears to be able to be shifted through developments in the situational self. Murray and Male (2005) see this process of socialisation to be not passive but active - teacher educators seek a new identity within the Higher Education Institution. Houston et al., (2010:557) support this view, suggesting that teacher educators choose between alignment with a community founded on either practice or the 'university-academy'. 
Grounded by our developing comprehension of the complex and on-going nature of identity development, we sought to understand further the process of 'learning to be', both for those within our own School and for those situated in partnership schools who were newly developing the role usually undertaken by teacher educators situated in Schools of Education. We used a series of empirical research studies to achieve this purpose.

\section{Research Approach}

This paper draws on four practitioner research projects which used a range of methodologies including self-study, case study and action research to explore the process of academic identity development. The projects share a broadly qualitative interpretive approach, used to examine thoughts, perceptions and beliefs. Data was collected in all the projects through semi-structured interviews. Themes were drawn from interview transcripts using a deductive approach from the questions and an inductive approach to the interview transcripts (Rubin and Rubin, 2005) to avoid missing new perspectives brought by the interviewees.

The insider researcher nature of all of the projects had a number of implications. Hellawell (2006) argues that the researcher must be both inside and outside the perceptions of the researched. He advocates that 'both empathy and alienation are useful qualities in a researcher', using the word 'alienation' here in its strictly Brechtian sense of distancing or making strange (Hellawell, 2006:487). Our insights into the development of identity in a University School of Education are presented below as a series of personal views for ease of explanation and to more coldly link our developing understanding to the set of scaffolds introduced above. However, the meta-analysis undertaken through our joint discussion of the learning from all our projects allowed us to apply a distancing approach to data which had become familiar, thus strengthening the validity of our interpretations.

\section{Mary's perspective: The academic apprentice}

My interest began with 'noticing' (Mason, 2001) that colleagues coming into this School of Education saw their identity as being one of a school teacher moving into a business of training other school teachers, rather than moving to a new identity of an academic. I wanted to understand their experience of 'learning to be' in the School of Education. Becher and Trowler (2001) recognise that the development of an academic identity does not follow a precise route of socialisation into an existing field. All of our research projects revealed individuals creating or developing new identities as a result of day to day interactions. Through these interactions with colleagues, who serve to challenge and shape, there was a coming to an understanding of tacit knowledge, a body of knowledge of 'how to be' that was often unarticulated. My study investigated these interactions and the meaning that new teacher educators derived from them. Participants in this research were apprenticed through a mixture of activities and relationships, according to the role they were going to take on. Responding to Lave and Wenger's (1991) invitation to use their examples of apprenticeships to begin a discussion of how they might relate to other contexts, fields or disciplines, the descriptions of apprenticeship for a range of contexts were used to consider the position of the adept in relation to the apprentice and also the nature of the curriculum - what had to be learned. Fields emerging included; apprentice as assistant to an adept, apprentice as novice and apprentice as peer, all of which were apparent in the experience of the respondents. 
Analysis of interview data revealed synergies with many of Lave and Wenger's examples, but also some discontinuities. For example, there was no sense in my data that there is one adept or that there is a pattern or system regarding who takes on the role and what the apprenticeship consists of. The apprentice selects and uses different adepts according to the activity s/he is engaged in. Hence participants reveal different aspects of their apprenticeship. This seems the obverse of an apprentice processes described by Lave and Wenger, where the genesis of the task begins with the adept as the experienced other. Likewise, my data revealed little formality in the relationship between adept and apprentice and no set curriculum of skills to be learned. Rather, the development is apprentice led according to perceived current need. Neither is there any apparent formal understanding of the two roles involved. In one sense, it is incumbent on the apprentice to identify their needs but there is also a strong sense that the institution as a whole is supporting and modelling what it is to be. Participants perceived a culture in the School of Education that was collaborative and supportive, demonstrated by colleagues' positive attitudes and they therefore became involved in that culture in different ways, depending on the role they took on.

There appeared to be, then, no one pathway through apprenticeship, due to the different starting points and different terrains of practice. There is no one example of academic which is shown to the newcomer and to which s/he aspires. The apprentice engages with the different terrains within the field according to their existing expertise on entering the School. Thus the term of 'apprentice as tenderfoot' seems relevant, a term coming from a mining context in North America. Someone coming into the School of Education has to cover a range of terrains, the selection of which seems to be dependent on the interest and expertise of the apprentice as well as the needs of the organisation. On moving over and across the terrain, the degree of confidence the newcomer has is varied. Some aspects are more familiar than others and the foot is surer, some are approached more tentatively and require more support from experienced others. Some are not approached at all.

There are three implications of this revealed process of 'learning to be'. The first is that it is to some extent the responsibility of the newcomer him/herself to determine how much and what kind of support s/he needs. The second is that the choice of direction on the terrain, particularly as time goes on, appears to be in the hands of the apprentice themselves. Accepting these two implications, the third is the difficulty of coherent strategic management of this diversity. As the terrain itself shifts, it becomes more difficult to predict the shape of a workforce with the relevant skills for the future.

\section{Liz's perspective: from teacher to teacher educator}

As discussed above, the process of evolving from teacher to teacher educator in a School of Education is a demanding one, involving the construction of a new identity (Murray and Male, 2005; Swennen et al., 2010). As part of this process, teaching experience needs to be recontextualised to support the learning of student teachers. As a new teacher educator, working part-time as a science teacher and part-time in a School of Education, I have reflected on how I have progressed in my expertise and grown in confidence as a teacher educator. My experience prior to teaching science in a secondary school was as a research scientist with a number of publications in my field. Therefore I brought with me to this new field a prior understanding of academic life and writing, albeit from twenty five years previously. Different aspects of my past and present experiences have enabled me to have a number of 'faces' that I have drawn on to meet the challenge of developing a 
new academic identity for my evolving new role. This has been a dynamic and on-going process as new opportunities have arisen.

When I first began at the School of Education, I planned to teach the student teachers using interactive strategies, so that they could engage more actively with the content and develop their professional knowledge in a socio-constructive environment. I strongly believed that it was important to model good practice in common with many other teacher educators (Loughran and Berry, 2005; Lunenberg et al., 2007; Russell, 2007). I made the assumption that this strategy would be well received by the student teachers, and would enable them to teach in a similar way. However, written evaluations of sessions after the first term revealed that many student teachers preferred a didactic approach rather than the use of more interactive strategies. Some perceived the activities as trivial and taking up too much time and were frustrated as they did not want to learn in this way. I therefore decided to use a self-study to examine my own practice as a new teacher educator, for my own professional development and to better meet the needs of my learners (White, 2011).

I reflected on my own teaching experience and explored the academic literature to identify aspects of my own professional knowledge as a teacher and to determine how I was going to expedite the growth of this professional knowledge in student teachers. Through constructive conversations with more experienced colleagues I discovered modelling needed to be explicit. This aspect of my teaching progressed, together with supporting the reflective practice of student teachers, by facilitating dialogue focussed on their learning so as to impact their practice. This concurs with the experience of other teacher educators (Lunenberg et al., 2007; Swennen et al., 2010). Adepts involved in my induction were experienced colleagues whose professional practice I observed; those that I sought constructive conversations with; and in particular a valued colleague who, at my request, mentored me through my initial endeavours at writing for publication.

In Schools of Education, this local community of practice can be extended to provide teacher educators with access to an international community of practice, itself generating and employing a communal repertoire of concepts and strategies (Bates et al., 2010).

The increasing focus on teacher training within schools in England (DfE, 2010) raises the importance of considering the professional development of new teacher educators who may be situated solely within a school environment. In this role, teacher educators are expected to lead sessions on pre-service training programmes; encourage student teachers to reflect on and assess their own teaching; provide resources and guidance on subject knowledge, learning theories and practices. Experienced teachers taking on this new role in school will have similar challenges with respect to their induction into the professional knowledge and practices of teacher educators as those situated within a university. However they may be geographically isolated from a local community of practice to guide and inform their practice and provide underpinning theory. Developing an identity as a teacher educator may similarly prove more challenging for those located solely in school.

Interviews with two teachers with this additional responsibility for teacher education revealed that initially the assumption was held that you only need experience as a teacher to teach student teachers effectively. However, during the first year of teaching a group of student teachers in school, the perspective of both these teachers changed, realising that taking on the role of teacher educator had professional development implications that might be addressed through a community of practice. This change in perspective was brought about partly by the interviewing approach, where teachers had the opportunity to develop as conversational partners with a more experienced teacher educator. 
Yes, definitely, I think it ... would have been useful to work out where you are at, before you can... help others, because then you can address the holes in your subject knowledge first.

Interview A

I think having even half a day to have someone [to] talk it through [with], and then you [can] start your thinking. That's always useful.

Interview

Their comments revealed their recognition of a need for access to a socio-constructive environment to examine the new professional knowledge required as a teacher educator with others experienced in the field. Swennen et al., (2008) suggest that the professional identity of teacher educators is also built in a socio-constructive way. These new teacher educators may be developing their situational identity with the student teachers in their school more rapidly than they are developing their substantive self through wider contact with emerging ideas and relationships with more experienced teacher educators. In order to have their substantive and situational selves aligned opportunities could be provided to nurture these new teacher educators through working alongside other teacher educators, building relationships through networking, mentoring, Masters' study and observation of more experienced practitioners. This would allow development of professional identity as well as professional knowledge within the wider community of practice.

\section{Amanda's perspective: from academic skills to academic identity}

As a newly appointed academic in the School of Education, I was excited by the opportunity to develop my professional identity in a new sector. However my assumptions about the nature of an academic identity are challenged by my current experience. Many colleagues do not undertake the research and writing activity which I imagined to be a core aspect of an academic's work. They are, however, committed to undertaking development projects focusing on better supporting student learning. Formal evaluation of these projects is rare. When it does occur, mechanisms for sharing what is learned within the School of Education or the wider education community are rarely fully realised.

My original interest lay in exploring the challenge for myself and my colleagues to engage in the writing process and then in the challenge faced by my university in promoting this activity. I wanted to develop my understanding of academics' experience of and response to writing and how they might be supported in producing written outcomes of their research and development activity. Initial 'exploratory conversations' (Ten Have, 1999; Rubin and Rubin, 2005) revealed much about colleagues' understanding of the writing process, their experiences of writing and their view of the institutional imperative to publish. I particularly noted colleagues' feelings of inadequacy in having the appropriate skills to write for publication, a common finding in Schools of Education (Bazeley, 1994; Avis et al., 2003).

I began to work with a research colleague who had similar interests. Issues of identity were prevalent in the initial exploratory conversations. We believed these issues would be remedied through the development of skills and the concomitant results in terms of publications. Drawing on the work of those experienced in the field of writing development (e.g. Lee and Boud, 2003; Moore, 2003; Murray, 2001; Murray and Mackay, 1998) and on previous work carried out within our School of Education (Chivers et al, 2010) we designed a Writing Support Programme to promote the development of 
appropriate skills for academic writing. This programme currently has a number of strands including:

- opportunities for colleagues to access one-to-one coaching

- opportunities to access regular writing workshops and weekend retreats

- the provision of 'Open Spaces' - informal seminars where colleagues can present their on-going research and development work

- the raising of awareness of colleagues' research and development activity through newsletters/visual display.

Initial response to the support on offer was encouraging.

I have found the newsletter and leaflet: 'Writing for dissemination' helpful and informative.

Colleague D - General feedback on Writing Support programme

It was useful to get a structure for an abstract - a helpful framework from which to work.

Colleague A - Feedback on 'Writing for publication' workshop

The focus on writing skills in this early feedback seemed to confirm the need for the development of skills-based practice. On-going evaluation of the programme has challenged our original view of the efficacy of such a skills-based approach to developing academics as writers, however. This view was predicated on an instrumental understanding of writing, of common barriers to it and of how they might be removed. In fact, skills development appears important but not for the purpose we imagined. In addition to helping colleagues to get words onto paper, colleagues found that developing writing skills allowed them to access a different aspect of their identity, as 'proper' academics (Chetty and Lubben, 2010). Colleagues identified ways in which their situational self, as a rounded academic, was developed through this activity. Such development led, in some cases, to increased confidence.

Both A and K's enthusiasm and confidence have given me the courage to step out in this area of writing. They make me believe I can do it!

Colleague D - General feedback on Writing Support programme

This insight into the 'lived experience of writing' (Carnell et al., 2008: ix) also points towards a more complex relationship between writing and identity.

The Open Space Forum has challenged me and given me a further opportunity to 'grow' in my research.

Colleague D - General feedback on Writing Support programme

Thank you so much for holding my hand with the proposal. I really needed it and can see myself doing it again.

Colleague F-Feedback on one-to-one coaching

These colleagues reference the impact of the Writing Support Programme both on their current perception of their academic identity and on their belief in their capacity for further development. Savin-Baden's (2008) view of writing as a transitional process in the 
constant re-framing of academic identity seemed to be played out here. We had previously seen the programme as simply a mechanism for jump-starting academics into writing habits. We now began to see it as a vehicle for long-term support, responding to individuals' changing roles in turbulent times. The writing which colleagues are undertaking appears to be both a conduit to and a manifestation of this shifting academic identity, itself not a state to be known but a 'dynamic and contested' entity to simply be (Welmond, 2002:42). It is the development of this sense of being, and the way in which writing can be used to move towards it, which is now our central interest.

\section{Emerging Insights}

The difficulties for teachers in establishing their identity following the move from school to university are well documented (Maguire, 2000; Harrison and McKeon, 2008). Murray (2008) suggests that the result of a backward glance towards a previous identity as a school teacher produces a lack of confidence towards academic roles and research. The process of identity change is, however, not a single move from teacher to teacher educator but rather is an on-going reconfiguration of academic identity as a career-long process. We are convinced that articulating the process and engaging individuals in 'learning to be' rather than 'learning to do' is an important aspect of survival and success in a turbulent environment. Reviewing our learning from our related research projects has led to some shared insights with respect to the nature of academic identify and its individual construction for teacher educators.

The research undertaken by Mary and Liz demonstrates the potential power of adepts within a community of practice to withstand the shifting environment and to provide ongoing, effective support for 'newcomers'. Engagement with communities of practice is seen to be of paramount importance for the development of professional knowledge and academic identity, both within the university setting and also for those undertaking the function of teacher-educators outside of the traditional structures of the academy. Such an approach allows for the development of the substantive self though engagement with the communal repertoire of beliefs and practices. It would not be realistic to expect teachers in schools who are involved in initial teacher education to develop academic identities as teacher educators encompassing the same extent of scholarly and academic activity as those who work full-time as teacher educators within a university setting. However, these teachers need opportunities to be engaged with adepts in a community of practice in order to develop their practice and identity adequately to support them in fulfilling the teacher educator aspect of their role. The accessibility of adepts could be a big challenge in the induction and professional development of these new teacher educators.

Amanda's research challenges set identity positions such as teacher versus teacher educator, offering instead scaffolds for colleagues to develop an understanding of the value of scholarship and of their potential to develop a more multi-faceted identity. Academic writing is thus re-framed from an individual activity associated with superior intellectual capacity and professional competitiveness to a collaborative, social activity (Carnell et al., 2008) which impacts on the learning of teachers, students and the organisation.

The importance of the community of practice as an enabling environment for change is an area for further investigation. From our data it appears that the change process does not conform to a common pattern for individuals but is rather dynamic and shifting in response to personal preference, skills, opportunities and challenge. Induction processes, often patchy and inappropriate (Harrison and McKeon, 2008), do not appear to adequately support this complex process of transformation. Indeed it could be argued that such a 
fixed development programme would be necessarily organisationally inefficient and disappointing for individuals. Instead, individuals need to be supported through the process of 'learning to be'. The value of providing a static development map for individuals is severely reduced in times of uncertainty. Instead, teacher educators need to be sustained in developing their own map during a continuous journey of self-discovery. The shifting terrain can then become a stimulus to development rather than an impediment.

Individuals are constantly defining, and redefining, what they do and how they might explain this to others (Whitchurch, 2007). The insights gained from our research projects suggest that it may be that this explanation, this need to articulate our practice and the values on which it rests (Shaw, 2002), which helps us to define how we are both to be and to act. We believe that it is important to surface the debate in our communities about the ways in which academic identity develops.

\section{References}

ARCHER, L. (2008) The new neoliberal subjects? Young/er academics' constructions of professional identity. Journal of Education Policy, 23, 265-285.

AVIS, J., KENDAL, A. \& PARSONS, J. (2003) Crossing the boundaries: expectations and experience of newcomers to higher and further education. Research in PostCompulsory Education, 8, 179-196.

BARNETT, R. (1990) The Idea of Higher Education, Buckingham, SRHE and Open University Press.

BARNETT, R. (2007) A will to learn, Milton Keynes, Open University Press.

BATES, T., SWENNEN, A. \& JONES, K. (2010) The Professional Development of Teacher Educators, Abingdon, Routledge.

BAZELEY, P. (1994) From vocational college to new university: the research profile and development needs of academic staff in a period of transition. Higher Education Research and Development, 13, 121-132.

BECHER, T. \& TROWLER, P. R. (2001) Academic Tribes and Territories. , Buckingham, SRHE \& Open University Press.

BLACKMORE, P. (1999) A categorisation of approaches to occupational analysis. Journal of Vocational Education and Training, 51, 61-78.

CARNELL, E., MACDONALD, J., MCCALLUM, B. \& SCOTT, M. (2008) Passion and politics. Academics reflect on writing for publication, London, Institute of Education.

CHETTY, R. \& LUBBEN, F. (2010) The scholarship of research in teacher education in a higher education institution in transition: issues of identity. Teaching and Teacher Education, 26, 813-820.

CHIVERS, L., COLLINS, C., LEE, L., SOLLY, D., DICKERSON, C., JARVIS, J. \& LEVY, R. (2010) Enhancing the induction process of new teacher educators through a selfstudy group. International Conference on Self-Study of Teacher Education Practices. Herstmonceux Castle.

CHURCHMAN, D. (2006) Institutional Commitments, Individual Compromises: Identity and related responses to compromise in an Australian university. Journal of Higher Education Policy \& Management, 28, 3-15.

CLEGG, S. (2008) Academic identities under threat? British Educational Research Journal, 34, 329-345. 
CLEMANS, A., BERRY, A. \& LOUGHRAN, J. (2010) Lost and found in transition: the professional journey of teacher educators. Professional Development in Education, $36,211-228$.

DEEM, R., HILLYARD, S. \& REED, M. (2007) Knowledge, Higher Education, and the New Managerialism. , Oxford, Oxford University Press.

DFE (2010) The Importance of Teaching: Schools White Paper.

DUCHARME, E. (1993) The lives of teacher educators. New York, Teachers College Press.

HARRISON, J. \& MCKEON, F. (2008) The formal and situated learning of beginning teacher educators in England: identifying characteristics for successful induction in the transition from workplace in schools to workplace in higher education. European Journal of Teacher Education, 31, 151 - 168.

HELLAWELL, D. (2006) Inside-out: analysis of the insider-outsider concept as a heuristic device to develop reflexivity in students doing qualitative research. Teaching in Higher Education, 11, 483-494.

HENKEL, M. (2005) Academic Identity and Autonomy revisited. IN BLEIKLIE, I. \& HENKEL, M. (Eds.) Governing knowledge: a study of continuity and change in higher education: a festschrift in honour of Maurice Kogan. Springer Verlag.

HOUSTON, N., ROSS, H., ROBINSON, J. \& MALCOLM, H. (2010) Inside research, inside ourselves: teacher educators take stock of their research practice. Educational Action Research, 18, 555 - 569.

LAVE, J. \& WENGER, E. (1991) Situated learning: Legitimate peripheral participation. Cambridge, Cambridge University Press.

LEE, A. B., D. (2003) Writing groups, change and academic identity: research development as local practice. Studies in Higher Education, 28, 187-200.

LOUGHRAN, J. \& BERRY, A. (2005) Modelling by teacher educators. Teaching and Teacher Education, 21, 193-203.

LUNENBERG, M., KORTHAGEN, F. \& SWENNEN, A. (2007) The teacher educator as a role model. Teaching and Teacher Education, 23, 586-601.

MACFARLANE, B. (1998) Business Lecturers in higher education: outsider reputations, insider values, Higher Education Close Up. Preston, University of Central Lancashire.

MACFARLANE, B. \& HUGHES, G. (2009) Turning teachers into academics? The role of educational development in fostering synergy between teaching and research. Innovations in Education and Teaching International, 46, 5-14.

MAGUIRE, M. (2000) Inside/Outside the Ivory Tower: Teacher Education in the English Academy. Teaching in higher education, 5, 149-165.

MASON, J. (2001) Researching Your Own Practice: The Discipline of Noticing, Abingdon, Routledge-Falmer.

MCCAFFERY, P. (2004) The Higher Education Manager's Handbook, Abingdon, RoutledgeFalmer.

MOORE, S. (2003) Writers' retreats for academics: exploring and increasing the motivation to write. Journal of Further and Higher Education, 27, 333-342.

MURRAY, J. (2004) A different sort of academic? Perspectives on academic life from Professional Educators involved in the initial education of teachers, nurses, social workers and doctors. British Education Research Conference. Manchester.

MURRAY, J. (2008) Teacher educators' induction into higher education: work-based learning in the micro communities of teacher education. European Journal of Teacher Education, 31, 117-133.

MURRAY, J. \& MALE, T. (2005) Becoming a teacher educator: evidence from the field. Teaching and Teacher Education 21, 125-142. 
MURRAY, R. E. G. (2001) Integrating teaching and research through writing development for students and staff. Active Learning in Higher Education, 2, 31-45.

MURRAY, R. E. G. \& MACKAY, G. (1998) Supporting academic development in public output: reflections and propositions. International Journal for Academic Development, 3, 54-63.

NIAS, J. (1989) Primary Teachers Talking. A study of teaching as work, London, Routledge.

RUBIN, H. \& RUBIN, I. (2005) Qualitative Interviewing, The Art of Hearing Data. London, Sage.

RUSSELL, T. (2007) How experience changed my values as a teacher educator. IN RUSSELL, T. \& LOUGHRAN, J. (Eds.) Enacting a pedagogy of teacher education. Values, relationships and practices. Abingdon, Routledge.

SAVIN-BADEN, M. (2008) Learning Spaces, Berkshire, Open University Press.

SCHEIN, E. H. (1985) Organisational culture and leadership. San Fransisco, CA, Jossey Bass.

SHAW, P. (2002) Changing Conversations in Organizations, London, Routledge.

SIKES, P. (2006) Working in a 'new' university: in the shadow of the Research Assessment Exercise? Studies in Higher Education, 31, 555-568.

STRONACH, I., CORBIN, B., MCNAMARA, O., STARK, S. \& WARNE, T. (2002) Towards an uncertain politics of professionalism: teacher and nurse identities in flux. Journal of Education Policy, 17, 109-138.

SWENNEN, A., JONES, K. \& VOLMAN, M. (2010) Teacher educators: their identities, subidentities and implications for professional development. Professional Development in Education, 36, 131-148.

SWENNEN, A., VOLMAN, M. \& VAN ESSEN, M. (2008) The development of the professional identity of two teacher educators in the context of Dutch teacher education. European Journal of Teacher Education, 31, 169 - 184.

TEN HAVE, P. (1999) Doing conversation analysis, London, Sage.

WELMOND, M. (2002) Globalization viewed from the periphery: The dynamics of teacher identity in the republic of Benin. Comparative Education Review, 46, 37-65.

WHITCHURCH, C. (2007) Beyond Boundaries - Finding a New Vocabulary. Higher Education Quarterly, 61, 406-408.

WHITE, E. (2011) Working towards explicit modelling: experiences of a new teacher educator. Professional Development in Education, 37, 483-497.

WHITE, J. \& WEATHERBY, R. (2005) Can universities become true learning organizations? The Learning Organization, 12, 292-298. 